\title{
Effect of Abomasal Administration of L-Glutamine on Nitrogen Balance and Plasma Amino Acid Concentrations in Young Calves
}

\author{
Tsunenori IRIKI, Kaoru YAMAZAKI*, \\ Masayuki FUNABA and Matanobu ABE \\ School of Veterinary Medicine, Azabu University, \\ Sagamihara--shi 229
}

(Received October 11, 1996)

\begin{abstract}
Holstein bull calves maintaining reflex closure of the esophageal groove after early -weaning were used to examine the effect of abomasal administration of $0.288 \mathrm{~g} / \mathrm{kg} \mathrm{BW} / \mathrm{d}$ of $\mathrm{L}$ glutamine $(\mathrm{Gln})$ on nitrogen $(\mathrm{N})$ balance and plasma amino acid concentrations. In Experiment 1 , comparisons with the administration of iso-nitrogenous diammonium citrate (DAC) were made from $9 \mathrm{wk}$ of age using 10 calves in a reversal method with five replicates and $2 \mathrm{wk}$-period. In Experiment 2, comparisons with that of DAC or iso-nitrogenous mixture of $0.111 \mathrm{~g} / \mathrm{kg} \mathrm{BW} / \mathrm{d}$ of $\mathrm{DL}$-methionine (Met) and $0.333 \mathrm{~g} / \mathrm{kg} \mathrm{BW} / \mathrm{d}$ of L-lysine monohydrochloride (LysHCl) were made from $14 \mathrm{wk}$ of age using 6 calves in a $3 \times 3$ Latin square design with two replicates and 2 wkperiod. Basal ration based on corn, soybean meal and rice straw was fed at $27 \mathrm{~g} / \mathrm{kg} \mathrm{BW} / \mathrm{d}$ in Experiment 1 , and at $20 \mathrm{~g} / \mathrm{kg} \mathrm{BW} / \mathrm{d}$ in Experiment 2. In both experiments, administration of LGln increased plasma GIn concentration only in the absorptive state, but $\mathrm{N}$ balance was not affected by abomasal $N$ supplements. Plasma concentrations of branched-chain amino acids did not differ between the supplements of $L-G \ln$ and DAC except for leucine, but were decreased by administration of DL-Met and L-LysHCl in Experiment 2.
\end{abstract}

Anim. Sci. Technol. (Jpn.) 68 (3) : 263-272, 1997

Key words : Branched-chain amino acids, Glutamine, Calves

A series of our experiments ${ }^{1,2)}$ indicated that plasma concentrations of branched-chain amino acids (BCAA) such as leucine (Leu), isoleucine (Ile) and valine (Val) were decreased by abomasal administration of DL-methionine (Met) independent of nitrogen ( $N$ ) balance. Some workers also reported linear decreases in plasma BCAA concentrations with abomasal infusion of increasing quantities of DL-Met or L-Met in sheep ${ }^{20)}$ and steers ${ }^{25)}$. These results strongly suggest an antagonistic interaction between Met and BCAA in ruminants, like the well-known antagonism within BCAA in chicks $^{24)}$ and rats ${ }^{\text {7)}}$. However, another possi- bility that abomasal supplement of L-glutamine (Gln) increased plasma BCAA concentrations is not neglected so far as our studies are concerned, because $\mathrm{L}-\mathrm{Gln}$ was used as a control or for adjustment of $\mathrm{N}$ intake in all $\mathrm{N}$ balance trials ${ }^{1,2)}$. The small intestine is the only one tissue where all the enzymes required to construct citrulline (Cit) from glutamatic acid (Glu) are assembled ${ }^{27)}$. Although both Gln and Glu are major respiratory fuels of enterocytes ${ }^{28,29)}$, activity of phosphate dependent glutaminase (GLNase) that converts Gln to Glu is the rate limiting step of GIn metabolism in the enterocytes ${ }^{28,29)}$. When an exces-

* Present address : Obihiro University of Agricultural and Veterinary Medicine, Obihiro-shi 080 
sive amount of exogenous Gin is supplied to enterocytes, a part of Gin escaped from the conversion may enter the portal vein. In the liver, Gln is once degraded by GLNase to give Glu and ammonia, but a part of the periportally consumed Gln is regenerated in the perivenous hepatocytes from the Glu and ammonia escaped from detoxification through the urea cycle $^{8,29}$. On the other hand, Gln is synthesized by transamination between BCAA and 2-oxoglutarate in the peripheral tissues such as skeletal muscle and adipose tissue ${ }^{24,27,29)}$. Thus, a large amount of exogenous GIn may increase plasma BCAA concentrations as a result of reduced uptake of $\mathrm{BCAA}$ by peripheral tissues for the endogenous Gin synthesis.

This study was conducted to compare the effects of a large amount of exogenous L-Gin and the iso-nitrogenous diammonium citrate (DAC) on $\mathrm{N}$ balance and plasma concentrations of amino acids, especially BCAA. The citrate is one of the metabolites of Gln carbons in the enterocytes ${ }^{27,28)}$, and not metabolized further in the enterocytes but easily converted to 2-oxoglutarate in the liver.

\section{Materials and Methods}

\section{Calves}

Two $\mathrm{N}$ balance experiments were conducted using a total of sixteen Holstein bull calves weaned at $5 \mathrm{wk}$ of age. They were trained after weaning to maintain reflex closure of the esophageal groove by offering warm water at the same time $(08: 30$ and $16: 30 \mathrm{~h})$ and by the same method (nipple feeding) under the same auditory environment (noise of routine and music from tape-recorder) as those at offering liquid milk replacer during the suckling period $^{1,2)}$. Water to quench thirst was offered by buckets at noon without music in order to discriminate motives of drinking liquid. Experiment 1 started from $9 \mathrm{wk}$ of age using 10 calves, whereas Experiment 2 started from 13 wk of age using 6 calves, after calves were stalled in individual cages. Mean BW of calves at the start of experiments was $74.5 \pm 7.0$ $\mathrm{kg}$ in Experiment 1, and $116.1 \pm 8.3 \mathrm{~kg}$ in Experiment 2.

\section{Basal ration}

The basal ration used in two experiments in common was similar to that used in the previous works ${ }^{1,2)}$, and consisted of $90 \%$ concentrate and $10 \%$ rice straw by as-fed weight. The concentrate consisted of $84 \%$ flaked corn, $14 \%$ rolled soy bean meal (SBM), and $2 \%$ minerals and vitamins ( $A$ and $D$ ), and contained $15.6 \%$ $\mathrm{CP}$ of $\mathrm{DM}^{1}$. Rice straw contained $4.5 \% \mathrm{CP}$ of DM. In Experiment 1, the basal ration was given at the level of $27 \mathrm{~g}$ on as-fed basis per $\mathrm{kg}$ BW in even portions at $08: 30$ and $19: 30 \mathrm{~h}$, so that daily CP intake was equivalent to $3.4 \mathrm{~g} / \mathrm{kg}$ $\mathrm{BW}$. In Experiment 2, however, daily $\mathrm{CP}$ intake was limited to $2.5 \mathrm{~g} / \mathrm{kg} \mathrm{BW}$ by restricting the feeding level of basal ration to $20 \mathrm{~g} / \mathrm{kg}$ $\mathrm{BW} / \mathrm{d}$, because the $\mathrm{CP}$ intake of $3.4 \mathrm{~g} / \mathrm{kg}$ was a little too high to identify limiting amino acids in Holstein bull calves above 3 mo of age, or more than $90 \mathrm{~kg} \mathrm{BW}$, according to our previous studies $^{10,11)}$.

\section{Experiments}

In Experiment 1, $\mathrm{N}$ balance and plasma concentrations of free amino acids were compared using 10 calves in a reversal design with five replicates and $2 \mathrm{wk}$-period between the two treatments : abomasal administration of 0.288 $\mathrm{g} / \mathrm{kg} \mathrm{BW} / \mathrm{d}$ of $\mathrm{L}-\mathrm{Gln}$ and that of the isonitrogenous $0.444 \mathrm{~g} / \mathrm{kg} \mathrm{BW} / \mathrm{d}$ of diammonium citrate (DAC). In Experiment 2, comparisons were made using 6 calves in a $3 \times 3$ Latin square design with 2 replicates and $2 \mathrm{wk}$-period among the three treatments : administration of $0.288 \mathrm{~g} / \mathrm{kg} \mathrm{BW} / \mathrm{d}$ of $\mathrm{L}-\mathrm{Gln}$, that of $0.444 \mathrm{~g} / \mathrm{kg}$ $\mathrm{BW} / \mathrm{d}$ of $\mathrm{DAC}$, and that of the iso-nitrogenous mixture of $0.111 \mathrm{~g} / \mathrm{kg} \mathrm{BW} / \mathrm{d}$ of DL-Met and $0.333 \mathrm{~g} / \mathrm{kg} \mathrm{BW} / \mathrm{d}$ of $\mathrm{L}-\mathrm{LysHCl}$. The supplemental $\mathrm{N}$ sources were administered through the esophageal groove by offering warm water dissolved each $\mathrm{N}$ source at $08: 30$ and $16: 30 \mathrm{~h}$ in even portions with nipple under the same 


\section{Exogenous Glutamine in Calves}

auditory condition as that before experiments. Feces and urine were collected for the last $5 \mathrm{~d}$ in every period. Jugular blood samples were also taken from every calf immediately before $(0 \mathrm{~h})$ and $3 \mathrm{~h}$ after the morning feeding and administration on the last day of each period. Analyses

The $\mathrm{N}$ contents of feed, supplemental $\mathrm{N}$ sources, feces and urine were determined by Kjeldahl method. Free amino acids in the plasma were determined by the method previously described ${ }^{9)}$. Data were analyzed by ANOVA using the GLM procedure of $\mathrm{SAS}^{23)}$. When treatment effect was significant $(\mathrm{P}<0.05)$ or tended to be significant $(\mathrm{P}<0.10)$ in Experiment 2 , the differences among means were tested for significance $(\mathrm{P}<0.05)$ or trend of significance $(\mathrm{P}<0.10)$ by Duncan's multiple range test.

\section{Results and Discussion}

\section{$N$ Balance}

Tables 1 and 2 present the $\mathrm{N}$ balance in Experiments 1 and 2, respectively. In Experiment 1 , any difference was not detected in $\mathrm{N}$ balance between the two treatments. In Experiment 2 , the $\mathrm{N}$ retained and the \% proportion of $\mathrm{N}$ retained to $\mathrm{N}$ intake tended to be lower with abomasal supplement of DAC among the three treatments. However, the tendency to decrease was due to a higher fecal $\mathrm{N}$ when DAC was supplemented, though not significant $(\mathrm{P}>0.10)$ and the reasons are unknown. The \% proportion of retained $\mathrm{N}$ to $\mathrm{N}$ absorbed did not differ in Experiment 2, indicating a similar availability of $\mathrm{N}$ absorbed

Table 1. Body weight (BW) and daily gain of calves and nitrogen $(\mathrm{N})$ balance in Experiment 1

\begin{tabular}{|c|c|c|c|c|}
\hline \multirow{2}{*}{ Jtem } & \multicolumn{2}{|c|}{ Treatment } & \multirow{2}{*}{ SEM } & \multirow{2}{*}{$\mathrm{P}<$} \\
\hline & $\mathrm{DAC}^{\mathrm{D}}$ & $\mathrm{L}-\mathrm{G} \mid \mathrm{n}^{2)}$ & & \\
\hline $\mathrm{n}$ & 10 & 10 & & \\
\hline Initial $\mathrm{BW}^{3)}, \mathrm{kg}$ & 78.2 & 77.2 & 0.4 & NS \\
\hline Final $\mathrm{BW}^{4}, \mathrm{~kg}$ & 84.4 & 84.3 & 0.5 & NS \\
\hline Daily gain, $\mathrm{kg}$ & 0.44 & 0.51 & 0.05 & NS \\
\hline \multicolumn{5}{|l|}{$\mathrm{N}$ balance, $\mathrm{g} / \mathrm{d}$} \\
\hline $\mathrm{N}$ intake $\mathrm{e}^{5 j}$ & 46.5 & 45.3 & 0.3 & NS \\
\hline$N$ in feces & 13.9 & 13.1 & 0.5 & NS \\
\hline $\mathrm{N}$ absorbed & 32.6 & 32.2 & 0.5 & NS \\
\hline $\mathrm{N}$ in urine & 8.9 & 9.5 & 0.7 & NS \\
\hline $\mathrm{N}$ retained & 23.7 & 22.7 & 0.7 & NS \\
\hline \multicolumn{5}{|c|}{$\mathrm{N}$ excreted into urine } \\
\hline$\%$ of $\mathrm{N}$ intake & 19.4 & 20.9 & 1. 6 & NS \\
\hline$\%$ of $\mathrm{N}$ absorbed & 27.5 & 29.4 & 2.0 & NS \\
\hline \multicolumn{5}{|l|}{$\mathrm{N}$ retention } \\
\hline$\%$ of $\mathrm{N}$ intake & 51.0 & 50.1 & 1.4 & NS \\
\hline$\%$ of $\mathrm{N}$ absorbed & 72.5 & 70.6 & 2.0 & NS \\
\hline
\end{tabular}

NS : $\mathrm{P}>0.10$.

1) Administration of $0.444 \mathrm{~g} / \mathrm{kg} \mathrm{BW} / \mathrm{d}$ of diammonium citrate through the esophageal groove.

${ }^{2)}$ Administration of $0.288 \mathrm{~g} / \mathrm{kg} \mathrm{BW} / \mathrm{d}$ of L-GIn through the esophageal groove.

${ }^{3)}$ Mean BW at the start of one treatment of the two.

4) Mean BW at the end of one treatment for $2 \mathrm{wk}$.

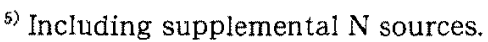


IRIKI, YAMAZAKI, FUNABA and ABE

Table 2. Body weight (BW) and daily gain of calves and nitrogen ( $N$ ) balance in Experiment 2

\begin{tabular}{|c|c|c|c|c|c|}
\hline \multirow[b]{2}{*}{ Item } & \multicolumn{3}{|c|}{ Treatment } & \multirow[b]{2}{*}{ SEM } & \multirow[b]{2}{*}{$\mathrm{P}<$} \\
\hline & $\mathrm{DAC}^{1)}$ & $L-G \ln ^{2)}$ & $\begin{array}{c}\mathrm{DL}-\mathrm{Met}+ \\
\left.\mathrm{L}-\mathrm{Lys} \mathrm{HCl}^{3}\right)\end{array}$ & & \\
\hline $\mathrm{n}$ & 6 & 6 & 6 & & \\
\hline Initial $\mathrm{BW}^{4}, \mathrm{~kg}$ & 118.0 & 116.5 & 117.0 & 0.8 & NS \\
\hline Final $\mathrm{BW}^{5}$, $\mathrm{kg}$ & 122.9 & 121.8 & 123.8 & 0.7 & NS \\
\hline Daily gain, $\mathrm{kg}$ & 0.34 & 0.38 & 0.49 & 0.06 & NS \\
\hline \multicolumn{6}{|l|}{$\mathrm{N}$ balance, $\mathrm{g} / \mathrm{d}$} \\
\hline$N$ intake ${ }^{6)}$ & 50.2 & 50.4 & 50.3 & 0.8 & NS \\
\hline$N$ in feces & 16.4 & 14.9 & 14.2 & 0.7 & NS \\
\hline $\mathrm{N}$ absorbed & 33.8 & 35.5 & 36.1 & 0.8 & NS \\
\hline $\mathrm{N}$ in urine & 15.1 & 15.7 & 16.1 & 0.6 & NS \\
\hline$N$ retained & $18.7^{\mathrm{b}}$ & 19. $8^{\mathrm{a}}$ & $20.0^{\mathrm{a}}$ & 0.4 & 0.08 \\
\hline \multicolumn{6}{|l|}{$\mathrm{N}$ excreted into urine } \\
\hline$\%$ of $\mathrm{N}$ intake & 30.2 & 31.2 & 31.9 & 0.9 & NS \\
\hline$\%$ of $\mathrm{N}$ absorbed & 44.8 & 44.2 & 44.5 & 0.7 & NS \\
\hline \multicolumn{6}{|l|}{$\mathrm{N}$ retention } \\
\hline$\%$ of $\mathrm{N}$ intake & $37.2^{b}$ & $39.3^{a}$ & $39.8^{a}$ & 0.7 & 0.07 \\
\hline$\%$ of $\mathrm{N}$ absorbed & 55.2 & 55.8 & 55.5 & 0.7 & NS \\
\hline
\end{tabular}

NS : $P>0.10$.

${ }^{a, b}$ Means in the same row with different superscripts tend to differ $(\mathrm{P}<0.10)$.

1) Administration of $0.444 \mathrm{~g} / \mathrm{kg} \mathrm{BW} / \mathrm{d}$ of diammonium citrate through the esophageal groove.

2) Administration of $0.288 \mathrm{~g} / \mathrm{kg}$ BW/d of L-Gln through the esophageal groove,

3) Administration of $0.111 \mathrm{~g} / \mathrm{kg} \mathrm{BW} / \mathrm{d}$ of DL-Met and $0.333 \mathrm{~g} / \mathrm{kg} \mathrm{BW} / \mathrm{d}$ of L-LysHCl through the esophageal groove.

4) Mean BW at the start of one treatment of the three.

5) Mean BW at the end of one treatment for $2 \mathrm{wk}$.

${ }^{6)}$ Including supplemental $\mathrm{N}$ sources.

among the three treatments.

In Experiment 2 using calves above 3 mo of age, $\mathrm{N}$ balance was not improved by abomasal administration of both DL-Met and $\mathrm{L}-\mathrm{LysHCl}$, in contrast to our previous studies ${ }^{1,2)}$ which showed that Met was first limiting and Lys second limiting for the similar diet as that used in this study under 3 mo of age. Reasons for the discrepancy are unclear, but it may be related to a rapid development of the rumen function after early-weaning. Leibhol ${ }^{17)}$ reported that microbial $\mathrm{N}$ as a percentage of total $\mathrm{N}$ flowing to the small intestine increased from $32 \%$ in the first week after weaning at $6 \mathrm{wk}$ of age to $74 \%$ by $7 \mathrm{wk}$ after the weaning. Quigley et al. ${ }^{19)}$ estimated that the proportion of microbial $\mathrm{N}$ flowing to the duodenum increased from $52.6 \%$ at $5 \mathrm{wk}$ of age to $71.2 \%$ at 11 wk of age in calves weaned at 4 wk of age, although the increase was not statistically significant. In addition, Vazquez-Anon et al. ${ }^{25)}$ reported that feedstuffs high in degradable protein such as SBM and corngluten feed had lower ruminal degradation rates during the first $4 \mathrm{wk}$ after weaning at $5 \mathrm{wk}$ of age than they did at $8 \mathrm{wk}$ after the weaning, although ruminal degradation rates of low degradable proteins did not change for $8 \mathrm{wk}$ after the weaning.

Proteins in corngluten meal (CGM) are known to be highly resistant against ruminal degradation $^{18)}$. When a diet containing CGM 
as a main protein source is fed to early-weaned calves, less degradable intake protein (DIP) would be supplied to rumen microbes as a $\mathrm{N}$ source independent of age after weaning. When a ration based on corn and CGM was fed to Holstein bull calves before 3 mo of age or under $90 \mathrm{~kg}$ BW, Lys was first limiting even if the $\mathrm{CP}$ intake from the ration was as high as 3.9 $\mathrm{g} / \mathrm{kg} \mathrm{BW} / \mathrm{d}^{10)}$. However, in calves after 3 mo of age or above $90 \mathrm{~kg}$ in BW, Lys was not limiting when $\mathrm{CP}$ intake from the corn-CGM ration was more than $3.9 \mathrm{~g} / \mathrm{kg} \mathrm{BW} / \mathrm{d}^{11}$, but limiting when the $\mathrm{CP}$ intake was restricted to $3.0 \mathrm{~g} / \mathrm{kg} \mathrm{BW} / \mathrm{d}^{12)}$. These results suggest that Lys becomes limiting when ruminal microbial synthesis is restricted, and that the restriction is obliged by underdevelopment of rumen function under 3 mo of age but by dietary factors such as the deficiency of DIP as a N source for microbes above 3 mo of age.

In Experiment 2, the basal ration based on corn and SBM was fed at the daily CP intake of $2.6 \mathrm{~g} / \mathrm{kg}$ BW to restrict microbial protein synthesis in the rumen. However, abomasal administration of DL-Met and L-LysHCL did not improve $\mathrm{N}$ balance, in contrast to calves under 3 mo of age $\mathrm{e}^{1.2)}$. It suggests that amino acids supplied by microbial protein and undegraded intake protein from corn and SBM were well utilized by the host, although the supply of total amino acids was not enough to the highest growth rate judging from lower daily gains shown in Table 2. Some workers have reported that Met was first limiting for steers when some dietary protein was furnished by $\mathrm{SBM}^{5,17)}$, but $\operatorname{Zinn}^{30)}$ reported that amino acid requirements for the daily gain of $1.48 \mathrm{~kg}$ in steers weighing 163 to $267 \mathrm{~kg}$ were fully met by the CP intake of $659 \mathrm{~g} / \mathrm{d}$, independent of the protein source of diets. Titgemeyer and Merchen ${ }^{25)}$ indicated that the requirement of sulfur-containing amino acids in $294 \mathrm{~kg}$ steers gaining $1.3 \mathrm{~kg}$ daily was less than the amount that would be supplied by diets containing corn based proteins. Although Met has been assumed to be first limiting in microbial protein ${ }^{16,22)}$, Buttery and Foulds ${ }^{4)}$ stated that microbial protein would not have any sole and strong limiting amino acid for dairy and growing cattle. Further studies are warranted to clarify the limiting amino acids for corn and SBM diets in calves above 3 mo of age.

Plasma Free Amino Acids

Tables 3 and 4 present plasma concentrations of free amino acids in Experiments 1 and 2 , respectively. Free amino acid concentrations in the plasma at $0 \mathrm{~h}$ were regarded as the representative reflection of post-absorptive state, whereas those at $3 \mathrm{~h}$ as that of absorptive state.

Only a little difference was detected between the abomasal supplements of DAC and $\mathrm{L}-\mathrm{Gln}$. In both experiments, plasma Gln concentration was increased by abomasal administration of L-Gin only in the absorptive state, suggesting the escape of L-Gin at least in part from conversion to Glu in the enterocytes. On the other hand, plasma concentrations of urea cycle constituents such as arginine (Arg), ornithine (Orn) and Cit tended to be higher with abomasal supplement of DAC with an exception of Orn in the absorptive state in Experiment 1, although urinary $\mathrm{N}$ excretion was not increased by the supplement of DAC (Tables 1 and 2).

Plasma BCAA concentrations did not differ between the supplements of L-Gin and DAC, except for Leu in the post-absorptive state in Experiment 1 and in the absorptive state in Experiment 2. However, the effect of L-Gin on plasma Leu concentration was different between the experiments. Plasma Leu was increased in Experiment 1 but decreased in Experiment 2 by abomasal supplement of L-Gin compared with that of DAC. Although reasons for the difference between experiments are unknown, the results suggest that the effect of exogenous GIn sparing plasma BCAA as precursors of endogenous Gln is quite limited, if possible. 
IRIKI, YAMAZAKI, FUNABA and ABE

Table 3. Concentrations $(\mu \mathrm{mol} / \mathrm{d} l)$ of plasma free amino acids $(\mathrm{AA})$ immediately before $(0 \mathrm{~h})$ and $3 \mathrm{~h}$ after the morning feeding in Experiment 1

\begin{tabular}{|c|c|c|c|c|c|c|c|c|}
\hline \multirow{3}{*}{ Item } & \multicolumn{4}{|c|}{ on } & \multicolumn{4}{|c|}{$3 \mathrm{~h}$} \\
\hline & \multicolumn{2}{|c|}{ Treatment ${ }^{1)}$} & \multirow{2}{*}{ SEM } & \multirow{2}{*}{$\mathrm{P}<$} & \multicolumn{2}{|c|}{ Treatment } & \multirow{2}{*}{ SEM } & \multirow{2}{*}{$\mathrm{P}<$} \\
\hline & DAC & L-Gln & & & DAC & L-GIn & & \\
\hline $\mathrm{n}$ & 10 & 10 & & & 10 & 10 & & \\
\hline \multicolumn{9}{|c|}{ Essential AA } \\
\hline Thr & 11.2 & 10.3 & 0.5 & NS & 7.9 & 7.3 & 0.5 & NS \\
\hline Val & 20.2 & 19.9 & 0.8 & NS & 16.4 & 16.3 & 0.9 & NS \\
\hline Met & 3.3 & 3.2 & 0.2 & NS & 1.9 & 1.8 & 0.2 & NS \\
\hline Ile & 9.0 & 8.9 & 0.3 & NS & 6.2 & 8.8 & 2.3 & NS \\
\hline Leu & 11.6 & 14.8 & 0.9 & 0.04 & 9.3 & 11.9 & 1.0 & NS \\
\hline Phe & 5.8 & 6.0 & 0.2 & NS & 4.1 & 4.2 & 0.4 & NS \\
\hline His & 5.8 & 6.0 & 0.2 & NS & 5.1 & 4.8 & 0.4 & NS \\
\hline Lys & 8.0 & 7.8 & 0.4 & NS & 5.6 & 4.8 & 0.5 & NS \\
\hline $\operatorname{Trp}$ & 4.6 & 4.4 & 0.3 & NS & 3.7 & 3.6 & 0.2 & NS \\
\hline Arg & 13. 6 & 12.0 & 0.5 & NS & 10.6 & 9.7 & 0.5 & NS \\
\hline \multicolumn{9}{|c|}{ Non-essential AA } \\
\hline Asp & 0.95 & 0.80 & 0.04 & 0.03 & 0.86 & 0.67 & 0.13 & NS \\
\hline Ser & 10. 1 & 10.8 & 0.5 & NS & 8.6 & 8.8 & 0.6 & NS \\
\hline Glu & 15.0 & 14.3 & 0.5 & NS & 13.6 & 12.6 & 0.8 & NS \\
\hline Gly & 52.8 & 56.3 & 2.3 & NS & 40.5 & 40.9 & 3.2 & NS \\
\hline Ala & 22.8 & 22.7 & 1.0 & NS & 22.9 & 19.0 & 1.5 & NS \\
\hline Cys & 1.88 & 1.51 & 0.08 & 0.02 & 1.85 & 1.64 & 0.11 & NS \\
\hline Tyr & 6.3 & 7. 1 & 0.2 & 0.03 & 4. 4 & 4.3 & 0.4 & NS \\
\hline Pro & 10.5 & 10.7 & 0.6 & NS & 11.3 & 13.3 & 0.9 & NS \\
\hline Gln & 23.3 & 22.2 & 1. 2 & NS & 20.3 & 34.3 & 2.5 & 0.01 \\
\hline Asn & 6.8 & 6.6 & 0.3 & NS & 5.0 & 5. 1 & 0.3 & NS \\
\hline Cit & 12.9 & 10.9 & 0.7 & 0.08 & 10.4 & 9.2 & 0.4 & 0.10 \\
\hline Orn & 7.1 & 6.1 & 0.4 & NS & 3.7 & 4.9 & 0.4 & 0.09 \\
\hline
\end{tabular}

NS : $\mathrm{P}>0.10$.

${ }^{1)}$ See the footnotes of Table 1.

Plasma tyrosine (Tyr) concentration was higher in the post-absorptive state in Experiment 1, when L-Gln was supplemented. However, plasma concentrations of phenylalanine (Phe) and Tyr were higher with the supplement of DAC in the absorptive state in Experiment 2 compared with that of L-Gln. Plasma concentrations of aspartate (Asp) and cysteine (Cys) were lower in the post-absorptive state when DAC was supplemented in Experiment 1, but the trend as such was not detected in Experiment 2. Plasma threonine ( $\mathrm{Thr}$ ) concentration was higher in the absorptive state in Experi- ment 2 with abomasal supplement of DAC compared with that of $\mathrm{L}-\mathrm{Gln}$, but the trend was not clear in Experiment 1. Reasons for these differences are also unknown, but the difference in age of calves and the feeding level of basal ration may be concerned with them.

As shown in Table 4, abomasal administration of both DL-Met and $\mathrm{L}-\mathrm{LysHCl}$ remarkably affected plasma concentrations of free amino acids. Plasma Met and Lys were increased by the administration not only in the absorptive state but also in the post-absorptive state compared with abomasal supple- 
Table 4. Concentrations $(\mu \mathrm{mol} / \mathrm{d} l)$ of plasma free amino acids (AA) immediately before $(0 \mathrm{~h})$ and $3 \mathrm{~h}$ after the morning feeding in Experiment 2

\begin{tabular}{|c|c|c|c|c|c|c|c|c|c|c|}
\hline \multirow{3}{*}{ Item } & \multicolumn{5}{|c|}{$0 \mathrm{~h}$} & \multicolumn{5}{|c|}{$3 \mathrm{~h}$} \\
\hline & \multicolumn{3}{|c|}{ Treatment } & \multirow[b]{2}{*}{ SEM } & \multirow{2}{*}{$\mathrm{P}<$} & \multicolumn{3}{|c|}{ Treatment } & \multirow[b]{2}{*}{ SEM } & \multirow[b]{2}{*}{$\mathrm{P}<$} \\
\hline & $\mathrm{DAC}$ & $\mathrm{L}-\mathrm{G} \ln$ & $\begin{array}{l}\text { DL-Met }+ \\
\text { L-Lys HCl }\end{array}$ & & & $\mathrm{DAC}$ & $\mathrm{L}-\mathrm{Gln}$ & $\begin{array}{l}\text { DL-Met }+ \\
\text { L-LysHCl }\end{array}$ & & \\
\hline $\mathrm{n}$ & 6 & 6 & 6 & & & 6 & 6 & 6 & & \\
\hline \multicolumn{11}{|c|}{ Essential AA } \\
\hline Thr & 12.7 & 13.5 & 11.4 & 0.7 & NS & $10.3^{a}$ & $8.9^{b}$ & $8.5^{b}$ & 0.3 & 0.01 \\
\hline Val & $25.8^{a}$ & $25.9^{a}$ & $19.5^{b}$ & 1.1 & 0.006 & 23. $7^{\mathrm{a}}$ & $21.9^{a}$ & 15. $2^{\mathrm{b}}$ & 0.8 & 0.001 \\
\hline Met & $3.7^{\mathrm{b}}$ & $3.6^{\mathrm{b}}$ & $50.6^{a}$ & 1.6 & 0.001 & $3.0^{b}$ & $2.9^{b}$ & $88.4^{a}$ & 1.8 & 0.001 \\
\hline Ile & $11.6^{\mathrm{a}}$ & $12.0^{\mathrm{a}}$ & $7.6^{6}$ & 0.6 & 0.002 & $8.4^{\mathrm{a}}$ & $6.8^{a}$ & $4.3^{\circ}$ & 0.7 & 0.008 \\
\hline Leu & $18.8^{\mathrm{a}}$ & $18.2^{a}$ & $11.5^{b}$ & 0.9 & 0.001 & $14.0^{a}$ & $11.0^{\mathrm{b}}$ & $6.5^{c}$ & 6.6 & 0.001 \\
\hline Phe & $6.5^{a}$ & $6.7^{n}$ & $5.0^{\mathrm{b}}$ & 0.3 & 0.009 & $5.5^{a}$ & $4.6^{b}$ & $3.9^{\circ}$ & 0.2 & 0.002 \\
\hline His & 6.4 & 7.2 & 7.0 & 0.4 & NS & 6.9 & 6.1 & 7.0 & 0.3 & NS \\
\hline Lys & $11.2^{\mathrm{b}}$ & $11.2^{\mathrm{b}}$ & $16.8^{a}$ & 0.5 & 0.001 & $6.4^{\mathrm{b}}$ & $7.2^{\mathrm{b}}$ & $65.6^{a}$ & 3.1 & 0.001 \\
\hline $\operatorname{Trp}$ & 3.8 & 3.9 & 3.5 & 0.1 & NS & 2.8 & 2.8 & 2.5 & 0.1 & NS \\
\hline Arg & 16.0 & 16.3 & 15.0 & 0.9 & NS & $15.6^{d}$ & $12.9^{e}$ & $15.9^{d}$ & 0.8 & 0.07 \\
\hline \multicolumn{11}{|c|}{ Non-essential AA } \\
\hline Asp & 2.1 & 2.2 & 2.2 & 0.2 & NS & 1.7 & 1.6 & 1.6 & 0.1 & NS \\
\hline Ser & $10.5^{b}$ & $12.0^{\mathrm{b}}$ & $14.2^{\mathrm{a}}$ & 0.5 & 0.002 & $9.3^{b}$ & $9.1^{b}$ & $12.0^{\mathrm{a}}$ & 0.5 & 0.006 \\
\hline Glu & 22.3 & 25.0 & 21.5 & 0.9 & NS & $22.9^{a}$ & $28.5^{a}$ & $18.7^{\mathrm{b}}$ & 1.4 & 0.003 \\
\hline Gly & 42.7 & 47.9 & 48.3 & 1.7 & NS & 41.4 & 36.8 & 43.0 & 2.2 & NS \\
\hline Ala & $27.3^{b}$ & $29.0^{b}$ & $33.0^{a}$ & 1. 1 & 0.02 & $29.4^{b}$ & $25.1^{b}$ & $34.0^{\mathrm{a}}$ & 1.6 & 0.02 \\
\hline Cys & $2.2^{\mathrm{b}}$ & $2.4^{\mathrm{b}}$ & $2.9^{\mathrm{a}}$ & 0.1 & 0.002 & $2.5^{\mathrm{b}}$ & $2.7^{b}$ & $3.2^{\mathrm{a}}$ & 0.1 & 0.005 \\
\hline Tyr & 8.1 & 8.3 & 7.8 & 0.4 & NS & $6.7^{\mathrm{d}}$ & $4.6^{f}$ & $5.8^{\circ}$ & 0.6 & 0.08 \\
\hline Pro & 10.9 & 10.9 & 11.0 & 0.4 & NS & 10.8 & 10.3 & 10.8 & 0.7 & NS \\
\hline Gln & 16.1 & 20.3 & 16.9 & 1.9 & NS & $13.0^{\mathrm{b}}$ & $21.0^{a}$ & $12.1^{b}$ & 0.7 & 0.005 \\
\hline Asn & Trace & Trace & Trace & - & - & Trace & Trace & Trace & - & - \\
\hline Cit & 10.2 & 10.0 & 9.0 & 0.5 & NS & $11.3^{\mathrm{a}}$ & $9.3^{a}$ & $7.0^{b}$ & 0.7 & 0.007 \\
\hline Orn & $9.7^{\mathrm{a}}$ & $8.4^{b}$ & $7.3^{c}$ & 0.4 & 0.008 & 6.3 & 6.1 & 7.0 & 0.5 & NS \\
\hline
\end{tabular}

NS : $\mathrm{P}>0.10$.

a, b, c Means in the same row with different superscripts differ $(P<0.05)$.

d.e.f Means in the same row with different superscripts tend to differ $(\mathrm{P}<0.10)$.

1) See the footnotes of Table 2 .

ments of $\mathrm{L}-\mathrm{G}$ ln and DAC. The concentrations were 1.5 to 2 times higher than when the same levels of DL-Met $(0.111 \mathrm{~g} / \mathrm{kg} \mathrm{BW} / \mathrm{d})$ and $\mathrm{L}^{-}$ LysHCl $(0.333 \mathrm{~g} / \mathrm{kg} \mathrm{BW} / \mathrm{d})$ were supplemented in calves under $3 \mathrm{mo}$ of age ${ }^{1.22}$. According to Japanese Feeding Standard for Beef Cattle $(1995)^{13)}$, CP requirement per unit BW of calves decreases with advancing age or increasing $\mathrm{BW}$. That is, the $\mathrm{CP}$ requirement of 75 and 125 $\mathrm{kg}$ dairy steers gaining $1.0 \mathrm{~kg}$ daily is 7.4 and 5.1 $\mathrm{g} / \mathrm{kg} \mathrm{BW} / \mathrm{d}$, respectively ${ }^{13)}$. The higher plas- ma concentrations of Met and Lys above 3 mo of age may reflect a greater excess of these acids than under 3 mo of age, so far as DL-Met and $\mathrm{L}-\mathrm{LysHCl}$ were dosed in proportion to $\mathrm{BW}$. Reis et $a l^{20)}$ reported that abomasal infusion of $10 \mathrm{~g} / \mathrm{d}$ of DL-Met in Merino wethers resulted in reduced wool growth rate in addition to an accumulation of free Met in the plasma as high as $235 \mu \mathrm{mol} / \mathrm{d} l$. However, reduced feed intake and depressed BW gain as ty pical symptoms of harmful effects were not exerted by the $a b$ - 
omasal supplement of DL-Met and L-LysHCl in Experiment 2, suggesting the irrelevance of unimproved $\mathrm{N}$ balance to the excess of Met and Lys.

Abomasal administration of DL-Met and LLysHCl decreased plasma BCAA concentrations not only in the absorptive state but also in the post-absorptive state compared with the supplement of L-Gin or DAC. Because $\mathrm{N}$ balance was not improved in Experiment 2, and because plasma BCAA concentrations were not affected by administration of the same level of $\mathrm{L}-\mathrm{LysHCl}{ }^{13}$ alone, the lowered plasma concentrations are considered to be exclusively due to supplemental DL-Met. Although an interaction between Met and BCAA has not been reported in chicks and rats, some workers also reported linear decreases in plasma BCAA concentrations with abomasal infusion of increasing quantities of $\mathrm{L}-\mathrm{Met}$ or DL-Met in steers ${ }^{25)}$ and in sheep ${ }^{203}$.

The administration of DL-Met and LLys HCl increased plasma concentrations of serine (Ser), alanine (Ala) and cysteine (Cys) in both absorptive and post-absorptive states, but decreased plasma Glu concentration only in the absorptive state compared with the administration of L-Gln or DAC. Because Ser is needed for the degradation of Met via Cys in the liver ${ }^{33}$, and because Ser is formed from Thr via Gly, excess of Met would often result in the Thr deficiency in rats ${ }^{6)}$ and chicks ${ }^{15)}$. In Experiment 2, abomasal administration of $\mathrm{DL}-$ Met and L-Lys $\mathrm{HCl}$ decreased plasma Thr concentration compared with that of DAC only in the absorptive state. However, it is unclear whether the decrease may prove the interaction between Met and Thr, because the Thr concentration was not lower than with the supplement of L-Gln. On the other hand, Lys is known to antagonize Arg in chicks ${ }^{14)}$. However, plasma Arg concentration was not decreased by the administration of DL-Met and $\mathrm{L}-\mathrm{LysHCl}$ in Experiment 2.

In conclusion, effects of exogenous $\mathrm{L}-\mathrm{G} \ln$ on
$\mathrm{N}$ balance and plasma BCAA concentrations were quite limited, if possible, at least when the dose was less than $0.288 \mathrm{~g} / \mathrm{kg} \mathrm{BW} / \mathrm{d}$. Antagonistic interaction between Met and BCAA was suggested to occur in calves also by the present study, in accordance with our previous studies $^{1,2)}$.

\section{Acknowledgments}

The authors wish to thank Keita Nagao for his technical assistence, and Ajinomoto Co, Inc. for providing amino acids and financial support. This research was also supported in part by a grant-in-aid (No. 04660311) for scientific research from the Ministry of Education, Science and Culture in Japan (1992-1993).

\section{References}

1) Abe $M$, Iriki $T$, Onda $S$, Iwano $F$, Funaba $M$. Effect of abomasal administration of lysine and methionine or lysine alone on nitrogen balance and plasma free amino acid concentrations in early-weaned calves fed a corn and soybean meal diet. Anim. Sci. Technol. (Jpn.), $67: 1058-1067.1996$.

2) Abe M, Sekine S, Funaba M, Irik: T. Limiting amino acids for early-weaned calves fed a corn and soybean meal diet and interaction among amino acids. Anim. Sci. Technol. (Jpn.), $68: 18-$ 28. 1997.

3) Benevenga NJ, Harper AW. Effect of glycine and serine on methionine metabolism in rats fed diets high in methionine. J. Nutr., $100: 1205$ -1214.1970 .

4) Buttery PJ, Foulds AN. Amino acid requirements in ruminants. In : Recent Advances in Animal Nutrition-1985. (Haresign W, Cole DAJ eds.) 257-272. Butterworths. London. 1985.

5) Fenderson CL, Bergen WG. An Assessment of essential amino acid requirements of growing calves. J Anim. Sci., 41 : 1759-1766. 1975.

6) Girard-Globa $A$, Robin P, Forestier M. Longterm adaptation of weanling rats to high dietary level of methionine and serine. J. Nutr. $102: 209-219.1972$.

7) Harper AE, Benevenga NJ, Wohlhueter RM. Effects of ingestion of disproportionate amounts of amino acids. Physiol. Rev., $50: 428-$ 458. 1970. 


\section{Exogenous Glutamine in Calves}

8) Häussinger D. Glutamine metabolism in the liver : overview and current concepts. Metabolism, $38:$ 14-17. 1989.

9) Iriki $T$, Nakamura $Y$, Yagioka $K$, Abe $M$. Effects of different degradation properties of dietary protein in the rumen on the weight gain and nitrogen balance at low or medium level of protein intake. Jpn. J. Zootech. Sci., 59:31-38. 1988.

10) Iriki $T$, Abe $M$, Suganuma $T$. Availability of ruminally undegraded protein from corn and corn gluten meal. Jpn. J. Zootech. Sci., 61 : 1063 $-1069.1990$.

11) Iriki $T$, Morita $K$, Abe M. Limiting amino acids in calves above 3 months of age when a lowlysine diet was given. Anim. Sci. Technol. (Jpn.), $62: 572-578.1991$.

12) Iriki $T$, Adachi $K$, Abe $M$. Necessity of ruminally undegraded dietary protein in 4-5 months-old calves under the condition of lowprotein intake. Anim. Sci. Technol. (Jpn.), 63: 414-419. 1992.

13) Japanese Feeding Standard for Beef Cattle (1995). Agriculture, Forestry and Fisheries Research Council Secretariat, MAFF. Tokyo. 1995.

14) Jones JD, Petersburg SJ, Burnett PC. The mechanism of the lysine-arginine antagonism in the chick : effect of lysine on digestion, kidney arginase, and liver transamidinase. J. Nutr., 93 : 103-116. 1967.

15) Katz RS, Baker DH. Methionine toxicity in chick : nutritional and metabolic implications. J. Nutr., 105 : 1168-1175. 1975.

16) Kaufman W, Lupping W. Protected proteins and protected amino acids for ruminants. In : Protein Contribution of Feedstuffs for Rumi. nants. (Miller EL, Pike LH, Van Es AJH eds.) 35-75. Butterworths. London. 1982.

17) Leibholz J. The development of ruminant digestion in the calf. I. The digestion of barley and soya bean meal. Aust. J. Agric. Res., 26 : 1081-1091. 1975.

18) National Research Council. Nutrient Requirements of Dairy Cattle. 6th revised ed. National Academic Press. Washington, DC. 1988.

19) Quigley, II JD, Schwab CG, Hylton WE. Devel- opment of rumen function in calves : nature of protein reaching the abomasum. J. Dairy Sci., $68: 694-702.1985$.

20) Reis PJ, Tumks DA, Sharry LF. Plasma amino acid patterns in sheep receiving abomasal infusions of methionine and cystine. Aust. J. biol. Sci., 26 : 635-644. 1973.

21) Rennie MJ, MacLennan PA, Hundal HS, Weryk B, Smith K, Taylor PM, Egan C, Watt PW. Skeletal muscle glutamine transport, intramuscular glutamine concentration, and muscle-protein turnover. Metabolism, $38: 47-$ 51. 1989.

22) Richardson CR, Hatfield EE. The limiting amino acids in growing cattle. J. Anim. Sci., $46: 740-745.1978$.

23) SAS User's Guide : Statistics, Version 6.08 . SAS Inst., Inc. Cary, NC. 1989.

24) Smith TK, Austic RE. The branched-chain amino acid antagonism in chicks. J. Nutr., 108 : 1180-1191. 1978.

25) Titgemeyer EC, Merchen NR. Sulfur-containing amino acid requirement of rapidly growing steers. J. Anim. Sci., 68:2075-2083. 1990.

26) Vazquez-Anon M, Heinrichs AJ, Aldrich JM, Verga GA. Effect of postweaning age on rate of in situ protein disappearance in calves weaned at 5 weeks of age. J. Dairy Sci., $76: 2749-2757$. 1993.

27) Wakabayashi Y. The glutamate crossway. In: Amino acid Metabolism and Therapy in Health and Nutritional Disease. 1st ed. (Cynober LA ed.) 89-98. CRC Press. Boca Raton. Florida. 1995.

28) Windmueller HG, Speath AE. Intestinal metabolism of glutamine and glutamate from the lumen as compared to glutamine from blood. Arch. Biochem. Biophys., 171 : 662-672. 1975.

29) Windmueller HG, Speath AE. Identification of ketone bodies and glutamine as the major respiratory fuel in vivo in post-absorptive rat small intestine. J. Biol. Chem., 255 : 69-76. 1978

30) Zinn RA. Crude protein and amino acid requirements of growing-finishing Holstein steers gaining 1.43 kilograms per day. J. Anim. Sci., $66:$ 1755-1763. 1988. 


\title{
幼齢子牛における L-グルタミンの第四胃内投与が窒素出納および 血漿遊離アミノ酸濃度に及ぼす影響
}

\author{
入来常徳・山崎 馨* ·舟場正幸・阿部又信 \\ 麻布大学獣医学部, 相模原市 229
}

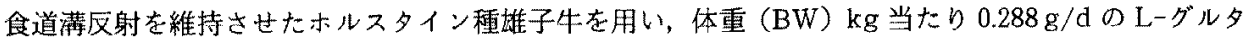


した. 実験 1 では 9 週榆から子牛 10 頭を供試し， 1 区 5 頭， 2 週間を 1 期とする反転法により等 $\mathrm{N}$ 量の クエン酸二アンモニウム（DAC）を投与した場合と比較した．実験 2 では 14 週齢から子牛 9 頭を供試 し，1区2頭，2週間を 1 期とする $3 \times 3$ ラテン万格法により等 $\mathrm{N}$ 量の DACまたは DLーメチオニン (Met) $0.111 \mathrm{~g} / \mathrm{kg} \mathrm{BW} / \mathrm{d}$ と-リジン塩酸塩 ( $\mathrm{LysHCl}$ ) $0.333 \mathrm{~g} / \mathrm{kg} \mathrm{BW} / \mathrm{d}$ の混合物を投与した場合との 3 処理間で比較した。トゥモロコシ・大豆粕・稲ワラを基本とする基礎飼料を実験 1 では 1 日に $27 \mathrm{~g} /$ kg BW の割合で給与したが, 実験 2 では $20 \mathrm{~g} / \mathrm{kg} \mathrm{BW}$ に制限して与えた. その結果, 両実験とも L-Gln

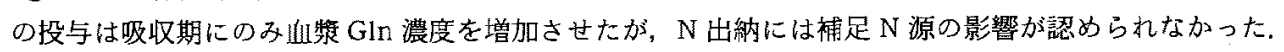
L-Gln とDAC の間では口イシン（Leu）を除いて血䠌側銷アミノ酸（BCAA）濃度に差がなく，血策 Leu 濃度に及济す影響あ実験 1 と 2 とでは異なった。実験 2 において，血墏 BCAA 漂度はDL-Met と L-LysHCl の同時投与に上り隇少した。 L-Gln の第四胃内投与が N 出納および血墏 BCAA 濃度に及代 す影響は決して大きくないことが示唆されたことに加えて，後者の減少は主としてDL-Met の投与に 起因するとの仮説が本研究において支支持された.
\end{abstract}

日畜会報, 68 (3)：263-272, 1997

* 現所属 : 帯広畜産大学, 帯広市 080

日畜会報, 68 (3) : 263-272 